\title{
Essential plant oils in reducing the intensity of soft rot in chinese cabbage $^{1}$
}

\author{
Óleos essenciais vegetais para a redução da intensidade da podridão mole em couve- \\ chinesa
}

\author{
Myrzânia de Lira Guerra ${ }^{2}$, Yrlânia de Lira Guerra², Elineide Barbosa de Souza² e Rosa de Lima Ramos \\ Mariano $^{2 *}$
}

\begin{abstract}
The action of essential oils in reducing soft rot in Chinese cabbage, and their influence on the colorimetry and physicochemical characteristics of the vegetable were evaluated. In the greenhouse, plants of the cultivar Natsume were sprayed with 11 oils selected in preliminary tests for phytotoxicity: bergamot, lemongrass, copaiba, Eucalyptus citriodora, blue gum, fennel, ginger, spearmint, sweet orange, lemon and clary sage $(0.5 \%)$ and also the antibiotic Mycoshield ${ }^{\circledast}\left(3 \mathrm{~g} \mathrm{~L}^{-1}\right)$. After 72 hours the plants were inoculated with Pectobacterium carotovorum subsp. carotovorum (Pcc-c). The oils and the Mycoshield ${ }^{\circledR}$ significantly reduced (P $\left.\leq 0.05\right)$ the severity (SEV) and the area under the disease progress curve (AUDPC). The oils of bergamot, copaiba, E. citriodora, spearmint and sweet orange were then tested for the stability of their effectiveness in the control of three isolates of $P$. carotovora subsp. carotovorum. These oils reduced the SEV (30.5 to 38.6\%) and the AUDPC (23.1 to 26.6\%) with no differences between them or the Mycoshield ${ }^{\circledR}$ (SEV 45.2 and AUDPC 32.8\%), except for the copaiba (20.3\%) which was less effective than the antibiotic in the reduction of the AUDPC. In vitro, only Mycoshield ${ }^{\circledR}$ inhibited the pathogen. None of the treatments altered the colorimetry, levels of ascorbic acid or $\mathrm{pH}$ of the leaves of the Chinese cabbage. The spearmint oil increased the total titratable acidity in the same way as the oils of sweet orange, E. citriodora and bergamot increased the total soluble solids. Therefore, spraying with the oils of bergamot, copaiba, E. citriodora, spearmint and sweet orange has potential in the control of this disease.
\end{abstract}

Key words: Brassica pekinensis. Alternative control. Pectobacterium carotovorum subsp. carotovorum. Physico-chemical characteristics. Colorimetry.

\begin{abstract}
RESUMO - A ação de óleos essenciais na redução da podridão mole em couve-chinesa e sua influência na colorimetria e características físico-químicas da hortaliça foram avaliadas. Em casa de vegetação, plantas da cultivar Natsume foram pulverizadas com 11 óleos selecionados em testes preliminares de fitotoxidez: bergamota, capim-limão, copaíba, Eucalyptus citriodora, E. globulus, funcho de erva-doce, gengibre, hortelã, laranja doce, limão siciliano e sálvia esclaréia a 0,5\%, e com o antibiótico Mycoshield ${ }^{\circledR}\left(3 \mathrm{~g} \mathrm{~L}^{-1}\right)$. Após $72 \mathrm{~h}$, as plantas foram inoculadas com Pectobacterium carotovorum subsp. carotovorum (Pcc-c). Os óleos e o Mycoshield ${ }^{\circledR}$ reduziram significativamente $(\mathrm{P} \leq 0,05)$ a severidade (SEV) e a área abaixo da curva de progresso da doença (AACPD). Os óleos de bergamota, copaíba, E. citriodora, hortelã e laranja doce foram então testados quanto à estabilidade da eficácia de controle em relação a três isolados de $P$. carotovorum subsp. carotovorum. Estes óleos reduziram a SEV $(30,5$ a 38,6\%) e a AACPD (23,1 a 26,6\%) sem diferirem entre si ou do Mycoshield ${ }^{\circledR}$ (SEV 45,2 e AACPD 32,8\%) exceto o de copaíba (20,3\%), menos eficiente que o antibiótico na redução da AACPD. Apenas Mycoshield ${ }^{\circledR}$ inibiu o patógeno in vitro. Nenhum tratamento alterou a colorimetria, teor de ácido ascórbico e pH das folhas da couve-chinesa. O óleo de hortelã elevou a acidez total titulável, assim como os óleos de laranja doce, E. citriodora e bergamota elevaram os sólidos solúveis totais. Portanto, a pulverização com os óleos de bergamota, copaíba, E. citriodora, hortelã e laranja doce têm potencial como medida de controle da doença.
\end{abstract}

Palavras-chave: Brassica pekinensis. Controle alternativo. Pectobacterium carotovorum subsp. carotovorum. Características fisico-químicas. Colorimetria.

\footnotetext{
*Autor para correspondência

${ }^{1}$ Recebido para publicação em 07/10/2013; aprovado em 08/06/2014

Parte do Trabalho de Dissertação no Programa de Pós-Graduação em Fitopatologia da UFRPE, com financiamento de bolsas FACEPE e CNPq concedida aos autores

${ }^{2}$ Programa de Pós-Graduação em Fitopatologia, Universidade Federal Rural de Pernambuco, Rua, Dom Manoel de Medeiros, s/n, Dois Irmãos Recife-PE, Brasil, 52.171-900, myrzgue@gmail.com, yrlalg@gmail.com, elineidebs@yahoo.com.br, rrmbac@gmail.com
} 


\section{INTRODUCTION}

In the state of Pernambuco in Brazil, Chinese cabbage (Brassica pekinensis L.) is a vegetable which is grown mainly in the Mata and the Agreste regions, with the municipalities of Vitória de Santo Antão and Chã Grande standing out as the main producers (CENTRO DE ABASTECIMENTOELOGÍSTICADEPERNAMBUCO, 2013). Soft rot, caused by Pectobacterium carotovorum subsp. carotovorum (Jones) Hauben et al., is the most important bacterial disease affecting the Chinese cabbage, because the symptoms of rot in the leaves prevents the vegetable from being marketed. In an epidemiological survey carried out in 22 areas of the Agreste region of Pernambucano where the Chinese cabbage is grown, the disease was found to have $100 \%$ prevalence, with an incidence ranging from 1 to $67 \%$ (SILVA et al., 2007).

Control of soft rot is hampered by the wide range of hosts of $P$. carotovorum subsp. carotovorum, its long period of survival in crop residues in the soil (REN; PETZOLDT; DICKSON, 2001; SILVA et al., 2012) and the high variability of the pathogen (ALVARADO et al., 2011). Recommended agricultural practices, such as the eradication of diseased plants, destruction of crop residues and the rotation of crops with grasses, are little used and are replaced by chemical control, which is generally inefficient. Despite there being no registered products, this being a 'minor crop', farmers use inappropriate products (MELLO et al., 2011) such as those from copper, for example.

In the control of disease and pests in cultivated plants, biologically active, natural substances are used, among which are essential plant oils (MORAIS, 2009), known for their bactericidal and fungicidal activity and their medicinal and flavouring properties (BURT, 2004), as well as for inducing resistance in plants through activation of biochemical defence pathways due to the amount of secondary metabolites existing in their constitution (GUIMARÃES et al., 2007).

The growing interest in natural products as alternatives in crop protection is due to their low impact on the environment (JEONG et al., 2009). However, when using alternative products to control diseases in edible vegetables in natura, such as the broadleaf vegetables, it is necessary to determine not only their efficiency in controlling disease but also whether the treatments employed will change the quality of the vegetable product. Among the most important indices of quality are colorimetry, which is a description of leaf colour in numerical terms, and physicochemical characteristics: ascorbic acid (vitamin C), total titratable acidity, potential of hydrogen $(\mathrm{pH})$ and total soluble solids ( ${ }^{\circ}$ Brix) (CHITARRA; CHITARRA, 2005).
Given that in some areas of the state of Pernambuco soft rot is a limiting factor in the production of Chinese cabbage and that effective measures to control the disease are difficult to implement, the aims of this work were to evaluate the action of essential oils in the control of soft rot in Chinese cabbage and verify the effect of these products on the colorimetry and physicochemical characteristics of the vegetable.

\section{MATERIAL AND METHODS}

Isolates of $P$. carotovorum subsp. carotovorum (Pcc-c, Pcc A1-1 and Pcc 83) were obtained from the Culture Collection of the Phytobacteriology Laboratory of the Federal Rural University of Pernambuco, having been obtained from Chinese cabbage plants showing symptoms of soft rot. These isolates were reactivated in a CPG medium (casein hydrolysate $1.0 \mathrm{~g}$, peptone $10 \mathrm{~g}$, dextrose $10 \mathrm{~g}$, agar $18 \mathrm{~g}$ and distilled water $1,000 \mathrm{~mL}$ ) and tested for pathogenicity and virulence in Chinese cabbage plants. For use in the experiments, the isolates were grown in a CPG medium for $36 \mathrm{~h}$, the concentration of the suspension being adjusted to $1.0 \times 10^{9} \mathrm{CFU} \mathrm{mL}^{-1}$ with a spectrophotometer (Analyser ${ }^{\circledR}$, São Paulo, Brazil).

In all the experiments, the Chinese cabbage hybrid, Natsume (AF-75) was used (Sakata Seed South America, Bragança Paulista, Brazil), one of those most cultivated in the producing municipalities of Pernambuco. Seeding was carried out in a greenhouse in polystyrene trays containing the agricultural substrate Basaplant ${ }^{\circledR}$ (Base Agro Industria e Comercio Ltda., São Paulo, Brazil) and after 15 days these were transplanted to plastic pots $(1,000 \mathrm{~mL})$ containing soil sterilised in an autoclave and humus (2:1).

The essential oils used were of bergamot (Citrus aurantium var. bergamia L.), lemongrass (Cymbopogon citratus Stapf), copaiba (Copaifera officinalis (Jacq.) L.), Eucalyptus citriodora Hooker M., blue gum (Eucalyptus globulus Labill), fennel (Foeniculum vulgare var. dulce Mill.), ginger (Zingiber officinale Roscoe), spearmint (Mentha piperita L.), sweet orange (Citrus sinensis (L). Osbeck), lemon (Citrus limon L. Burm. F.) and clary sage (Salvia sclarea L.), all 100\% pure and produced by Bioessência (Indústria Bioessência Produtos Naturais Ltda., São Paulo, Brazil).

To test for phytotoxicity, the essential oils were dispersed in distilled water to obtain concentrations of $0.0,0.3,0.5,0.8,1.0$ and $1.5 \%(\mathrm{v} / \mathrm{v})$, mixed with Tween 20 (1:1), agitated and applied with a manual spray to 40-day old Chinese cabbage plants until the leaf surface was completely wet. Evaluation of phytotoxicity consisted of noting the appearance of abnormalities in the development or colouring of the plants up to 48 hours after application of the treatments. 
The experiment to reduce the severity of soft rot was carried out in a similar manner to the phytotoxicity test, except that the essential oils were only tested at a concentration of $0.5 \%(\mathrm{v} / \mathrm{v})$. The agricultural antibiotic Mycoshield $^{\circledR}$, containing $200 \mathrm{~g} \mathrm{~kg}^{-1}$ of oxytetracycline was used for comparison at a concentration of $3 \mathrm{~g} \mathrm{~L}^{-1}$ of water. The control was treated with distilled water only. Seventy-two hours after undergoing these treatments the plants were inoculated with the Pcc-c isolate at the base of the petiole of the second and third leaves by the pricking method, consisting of a mild injury to the plant tissue with an entomological pin to a depth of $1 \mathrm{~mm}$ and deposition of $10 \mu \mathrm{L}$ of the bacterial suspension (MARIANO, SILVEIRA, 2005). After inoculation, the plants were placed for $6 \mathrm{~h}$ in a humidity chamber made of plastic bags internally moistened with water. The plants were kept in a greenhouse at a temperature of $33 \pm 2{ }^{\circ} \mathrm{C}$.

Disease severity (SEV) was assessed at intervals of $6 \mathrm{~h}$ until $48 \mathrm{~h}$ after inoculation, being estimated using a descriptive scale of 1 to 9 , where: $1=$ no lesion at the point of inoculation; $2=$ lesions smaller than $5 \mathrm{~mm} ; 3=$ lesions between 5 and $10 \mathrm{~mm} ; 4=$ lesions greater than $10 \mathrm{~mm}$, but not reaching the leaves; $5=$ lesion reaching the leaf blade and main stem; $6=$ infected stem, but not reaching the non-inoculated leaves; $7=$ stem and noninoculated leaves infected; $8=$ whole plant near death; 9 = dead plant (REN; PETZOLDT; DICKSON, 2001). From the SEV data, the area under the disease progress curve (AUDPC) was calculated according to Shaner and Finney (1977). The reduction in disease severity (RDS) compared to the control was calculated by equation 1 , adapted from Edginton, Khew and Barron (1971):

$R D S \%=[(S E V T-S E V T r) / S E V T] \times 100$

where: $S E V T=$ disease severity in the control and $S E V T r=$ disease severity for the treatment.

The experimental design was completely randomised with 13 treatments (11 essential oils, Mycoshield ${ }^{\circledR}$ and control) and five replications, each consisting of one plant.

The essential oils of bergamot, copaiba, $E$. citriodora, spearmint and sweet orange were selected for testing against three isolates of the pathogen (Pcc-c, Pcc A1-1 and Pcc 83), according to the methodology described for the previous experiment. The experimental design was completely randomised into a $3 \times 7$ factorial arrangement, represented by seven treatments (five essential oils, Mycoshield ${ }^{\circledR}$ and control) and three isolates of the pathogen, with five replications, each consisting of one plant.

To evaluate the effect of the five essential oils on the in vitro growth of $P$. carotovorum subsp. carotovorum, an antibiogram test was carried out using disks, as per Mariano and Silveira (2005). Incubation was conducted at $29^{\circ} \mathrm{C}$ for $24 \mathrm{~h}$ and evaluation made by measuring the inhibition halos with calipers. The experimental design was completely randomised, with seven treatments (five essential oils, Mycoshield ${ }^{\circledR}$ and control) and four replications, each consisting of a dish with five disks.

The effect was also evaluated of the essential oils of bergamot, copaiba, E. citriodora, spearmint and sweet orange $(0.5 \%)$ and of the agricultural antibiotic Mycoshield ${ }^{\circledR}$ on the colorimetry and the physicochemical characteristics of Chinese cabbage plants after inoculation with the Pcc-c isolate. All the methodology, including treatment, inoculation and incubation was similar to that of the first experiment.

The plants were collected $48 \mathrm{~h}$ after inoculation. Colorimetry was determined using a colorimeter (Konica Minolta CR-10, New Jersey, EUA) operating under a CIELab system, adjusted for the colour white (COSTA et al., 2011). The values of $\mathrm{L}^{*}, \mathrm{a}^{*}$ and $\mathrm{b}^{*}$ were obtained; where $\mathrm{L}^{*}$ represents luminosity, $\mathrm{a}^{*}$ defines the transition of the colour green $\left(-a^{*}\right)$ to red $\left(+a^{*}\right)$, and $b^{*}$ represents the transition of the colour blue $\left(-b^{*}\right)$ to yellow $\left(+b^{*}\right)$. Next the leaves were triturated in a domestic centrifuge and evaluated as to total soluble solids ( ${ }^{\circ}$ Brix) (FREIRE et al., 2009); ascorbic acid (vitamin $\mathrm{C}$ ), using the modified Tillman method (ZENEBON; SADOCCO; TIGLEA, 2008); total titratable acidity; and potential of hydrogen $(\mathrm{pH})$ (EVANGELISTA et al., 2009). The experimental design was completely randomised, with eight treatments (five essential oils, Mycoshield ${ }^{\circledR}$, control 1 (distilled water and $P$. carotovorum subsp. carotovorum), control 2 (distilled water only) and five replications, each consisting of one plant.

All the experiments were carried out twice. Since no significant differences $(\mathrm{P} \leq 0.05)$ were seen in the variances when replicating the experiments, the data were evaluated jointly. The results obtained were subjected to variance analysis (ANOVA) by F-test at $5 \%$ significance. The assumptions of ANOVA were checked by the Shapiro-Wilk and Levene tests. The Tukey test at 5\% was used to compare means, except for the colorimetric analyses where the Kruskal-Wallis test at $5 \%$ was used. The Statistix ${ }^{\circledR}$ software (version 9.0, Analytical Software, Tallahassee, USA) was used to analyse the data.

\section{RESULTS AND DISCUSSION}

None of the essential oils tested led to phytotoxicity of the Chinese cabbage plants at the concentration of $0.5 \%$, which was used in this work (data not shown).

The eleven essential oils and the agricultural antibiotic Mycoshield ${ }^{\circledR}$ significantly reduced $(\mathrm{P} \leq 0.05)$ disease severity in the greenhouse (Table 1). The spearmint 
oil and the Mycoshield ${ }^{\circledR}$ reduced the SEV in 53.1 and $38.8 \%$ respectively and the AUDPC by 37.0 and $27.5 \%$, when compared to the control.

Table 1 - Effect of essential oils $(0.5 \%)$ and the agricultural antibiotic Mycoshield ${ }^{\circledR} \quad\left(3 \mathrm{~g} \mathrm{~L}^{-1}\right)$ in reducing soft rot (Pectobacterium carotovorum subsp carotovorum, Pcc-c isolate) in Chinese cabbage plants in the greenhouse, assessed for disease severity (SEV) and area under the disease progress curve (AUDPC)

\begin{tabular}{|c|c|c|}
\hline Treatment & $\mathrm{SEV}^{1}$ & AUDPC $^{2}$ \\
\hline Control & $4.9^{3} \mathrm{a}$ & $123.3 \mathrm{a}$ \\
\hline Ginger & $3.3 \mathrm{~b}$ & $96.9 \mathrm{~b}$ \\
\hline Eucalyptus citriodora & $3.1 \mathrm{~b}$ & $97.5 \mathrm{~b}$ \\
\hline Blue Gum & $3.1 \mathrm{~b}$ & $93.9 \mathrm{~b}$ \\
\hline Lemon & $3.0 \mathrm{~b}$ & $89.4 \mathrm{~b}$ \\
\hline Mycoshield $^{\circledR}$ & $3.0 \mathrm{~b}$ & $89.4 \mathrm{~b}$ \\
\hline Fennel & $2.9 \mathrm{~b}$ & $91.5 \mathrm{~b}$ \\
\hline Sweet orange & $2.8 \mathrm{~b}$ & $85.8 \mathrm{~b}$ \\
\hline Lemongrass & $2.8 \mathrm{~b}$ & $86.4 \mathrm{~b}$ \\
\hline Copaiba & $2.7 \mathrm{~b}$ & $87.9 \mathrm{~b}$ \\
\hline Clary sage & $2.7 \mathrm{~b}$ & $84.9 \mathrm{~b}$ \\
\hline Bergamot & $2.6 \mathrm{~b}$ & $87.0 \mathrm{~b}$ \\
\hline Spearmint & $2.3 \mathrm{~b}$ & $77.7 \mathrm{~b}$ \\
\hline $\mathrm{CV}(\%)$ & 19.94 & 12.74 \\
\hline
\end{tabular}

${ }^{1}$ Estimated with the aid of a descriptive scale of 1 to 9 where: $1=$ no lesion at the point of inoculation; $2=$ lesions smaller than $5 \mathrm{~mm} ; 3$ $=$ lesions between 5 and $10 \mathrm{~mm} ; 4=$ lesions greater than $10 \mathrm{~mm}$, but not reaching the leaves; $5=$ lesion reaching the leaf blade and main stem; $6=$ infected stem, but not reaching the non-inoculated leaves; 7 = stem and non-inoculated leaves infected; $8=$ whole plant near death; 9 = dead plant (REN; PETZOLDT; DICKSON, 2001); ${ }^{2}$ Calculated according to Shaner and Finney (1977); ${ }^{3}$ Numbers are the averages of two experiments (ten repetitions). Averages followed by the same letter do not differ significantly by Tukey test $(\mathrm{P} \leq 0.05)$

Statistical analysis showed no significance $(\mathrm{P} \leq 0.05)$ for the interaction of the oils with the three isolates of $P$. carotovorum subsp. carotovorum when the essential oils of bergamot, copaiba, E. citriodora, spearmint and sweet orange and the Mycoshield ${ }^{\circledR}$ were tested for the stability of disease-control effectiveness. The analysis was carried out therefore fixing the factor for the oils, whose effectiveness had been verified. All the oils reduced disease severity (SEV and AUDPC), with no differences between them or the Mycoshield ${ }^{\circledR}$, except the copaiba oil which proved to be less effective than the antibiotic in reducing the AUDPC (Table 2).
The reduction in SEV by the oils ranged from 30.5 (copaiba) to $38.6 \%$ (bergamot) whereas that obtained with the agricultural antibiotic was $45.2 \%$. The reduction in AUDPC ranged from 23.1 (E. citriodora) to $26.6 \%$ (spearmint) compared to $32.8 \%$ from the Mycoshield ${ }^{\circledR}$ (Table 2). The lack of interaction between the oils and isolates of the pathogen is important in controlling soft rot as it means that these products will be effective even when the disease is caused by different isolates of the pathogen, especially taking into account the great variability of $P$. carotovorum subsp. carotovorum (ALVARADO et al., 2011).

Despite the absence of reports on the action of essential oils in the control of soft rot in Chinese cabbage, there are promising results using these products in lettuce. For that vegetable, the oil of E. citriodora at $0.5 \%$ stood out with a similar efficiency to the Mycoshield ${ }^{\circledR}$ in reducing the variables SEV (52.0 and 58.7\%) and AUDPC (37.0 and $48.5 \%$ ) respectively (SILVA et al., 2012).

In the antibiogram disc test, the growth of $P$. carotovorum subsp. carotovorum was not inhibited by the oils of E. citriodora, bergamot, spearmint, copaiba or sweet orange, but was inhibited by the Mycoshield ${ }^{\circledR}$ which

Table 2 - Effect of essential oils $(0.5 \%)$ and the agricultural antibiotic Mycoshield ${ }^{\circledR}\left(3 \mathrm{~g} \mathrm{~L}^{-1}\right)$ in reducing soft rot (Pectobacterium carotovorum subsp carotovorum isolates: Pcc-c; Pcc A1-1; Pcc 83) in Chinese cabbage plants in the greenhouse, assessed for disease severity (SEV) and area under the disease progress curve (AUDPC)

\begin{tabular}{lll}
\hline \multicolumn{1}{c}{ Treatment $^{1}$} & SEV $^{2}$ & AUCPC $^{3}$ \\
\hline Copaiba & $2.83^{4} \mathrm{~b}$ & $69.90 \mathrm{~b}$ \\
Bergamot & $2.50 \mathrm{~b}$ & $65.70 \mathrm{bc}$ \\
Spearmint & $2.60 \mathrm{~b}$ & $64.60 \mathrm{bc}$ \\
Eucalyptus citriodora & $2.70 \mathrm{~b}$ & $67.40 \mathrm{bc}$ \\
Sweet Orange & $2.60 \mathrm{~b}$ & $66.00 \mathrm{bc}$ \\
Mycoshield $^{\circledR}$ & $2.23 \mathrm{~b}$ & $58.90 \mathrm{c}$ \\
Control & $4.07 \mathrm{a}$ & $87.70 \mathrm{a}$ \\
CV $(\%)$ & 29.29 & 16.56 \\
\hline
\end{tabular}

${ }^{1}$ Analysis carried out fixing the oil factor since the interaction of oils and isolates was not significant $(\mathrm{P} \leq 0,05) ;{ }^{2}$ Estimated with the aid of a descriptive scale of 1 to 9 where: $1=$ no lesion at the point of inoculation; $2=$ lesions smaller than $5 \mathrm{~mm} ; 3=$ lesions between 5 and $10 \mathrm{~mm} ; 4=$ lesions greater than $10 \mathrm{~mm}$, but not reaching the leaves; $5=$ lesion reaching the leaf blade and main stem; 6 = infected stem, but not reaching the non-inoculated leaves; $7=$ stem and non-inoculated leaves infected; $8=$ whole plant near death; 9 = dead plant (REN; PETZOLDT; DICKSON, 2001); ${ }^{3}$ Calculated according to Shaner and Finney (1977); ${ }^{4}$ Numbers are the averages of two experiments (30 repetitions). Averages followed by the same letter do not differ significantly by Tukey test $(\mathrm{P} \leq 0.05)$ 
produced a halo of up to $29.6 \mathrm{~mm}$ in diameter. Other oils have shown to be effective against this pathogen, and some studies in vitro have shown the minimum inhibitory concentration for the essential oils of rosemary, basil and lemongrass to be 4.0, 2.0 and $0.5 \%$ respectively for various isolates of $P$. carotovorum subsp. carotovorum (COSTA et al., 2008; 2009; JEONG et al., 2009). Lemongrass at $0.5 \%$ completely inhibited the growth of this phytopathogenic bacterium (JEONG et al., 2009). The oils under study did not show any direct in vitro effect on the pathogen, and may be involved in controlling the disease by induced resistance. Essential oils have a wide variety of secondary metabolites in their makeup which may activate biochemical pathways of plant defence, such as the production of phytoalexins, as do the oils of the pitanga, lemongrass and basil which induced glyceolins in cotyledons of the soybean (GUIMARÃES et al., 2007). Lucas et al. (2012) found that the essential oil of the clove reduced the severity of bacterial spot in the tomato and induced increased activity of the PR proteins, $\beta$ 1.3-glucanase, chitinase and peroxidase, confirming this induced resistance.

Colorimetric analysis of Chinese cabbage leaves showed that luminosity $\left(\mathrm{L}^{*}\right)$ in plants treated with the oils of copaiba, sweet orange, spearmint, E. citriodora and bergamot did not differ significantly from those controls treated with distilled water and $P$. carotovorum subsp. carotovorum (control 1) or distilled water only (control 2) (Table 3). Only the Mycoshield ${ }^{\circledR}$ (43.92) significantly raised the luminosity in relation to control 2 (18.17). Neither the green $\left(-a^{*}\right)$ or yellow $\left(+b^{*}\right)$ colourations of the leaves were altered by the application of the tested products in relation to control 2.
No work using colorimetry and relating to the activity of essential oils in the control of soft rot in Chinese cabbage could be found in the literature consulted. However it is known that the appearance of leafy vegetables in relation to colour has great importance in acceptance and acquisition by the consumer, especially in the Chinese cabbage where increased yellowing in the harvested product indicates senescence (ABLE et al., 2005). Use of the tested oils would not therefore affect acceptance of the product by consumers.

For control 2, the level of ascorbic acid in the plants was not changed by the five oils under test, only being increased by the bacterial infection (control 1) and under the treatment with Mycoshield ${ }^{\circledR}$ (Table 4). Total titratable acidity was affected by the spearmint oil which, in a similar way to the treatment with the antibiotic and control 2, increased the values of this variable. The $\mathrm{pH}$ did not show any changes across the different treatments, and the ${ }^{\circ}$ Brix was significantly increased only in those plants treated with the oils of sweet orange, E. citriodora and bergamot.

In terms of overall amplitude, the ascorbic acid ranged from 1.80 (bergamot) to $3.80 \mathrm{mg} 100 \mathrm{~g}^{-1}$ $\left(\right.$ Mycoshield $\left.{ }^{\circledR}\right)$, the total titratable acidity ranged from 0.15 (control 2, sweet orange and bergamot) to 0.26 (Mycoshield ${ }^{\circledR}$ ), the $\mathrm{pH}$ ranged from 6.06 (bergamot) to 6.49 (copaiba) and the ${ }^{\circ}$ Brix from 0.87 (Mycoshield $^{\circledR}$ ) to 2.16 (bergamot) (Table 4). These results differ in relation to the levels of ascorbic acid listed by Centro Nacional de Pesquisa em Hortaliças (2010) for the Chinese cabbage (19.5 mg $\left.100 \mathrm{~g}^{-1}\right)$, probably due to the plants used in this study being cultivated for only

Table 3 - Colorimetric Analysis of Chinese cabbage plants treated with essential oils and the agricultural antibiotic Mycoshield ${ }^{\circledR}$ in the greenhouse

\begin{tabular}{lccc}
\hline \multicolumn{1}{c}{ Treatment $^{1}$} & $\mathrm{~L}^{* 2}$ & $\mathrm{a}^{*(-)}$ & $\mathrm{b}^{*(+)}$ \\
\hline Mycoshield $^{\circledR}$ & $43.92^{3} \mathrm{a}$ & $19.33 \mathrm{ab}$ & $43.00 \mathrm{a}$ \\
Control 1 & $34.08 \mathrm{ab}$ & $29.92 \mathrm{ab}$ & $29.00 \mathrm{a}$ \\
Bergamot & $26.00 \mathrm{ab}$ & $5.17 \mathrm{~b}$ & $20.25 \mathrm{a}$ \\
Eucalyptus citriodora & $21.67 \mathrm{ab}$ & $21.59 \mathrm{ab}$ & $21.33 \mathrm{a}$ \\
Spearmint & $18.75 \mathrm{ab}$ & $39.17 \mathrm{a}$ & $20.66 \mathrm{a}$ \\
Control 2 & $18.17 \mathrm{~b}$ & $17.33 \mathrm{ab}$ & $24.08 \mathrm{a}$ \\
Sweet orange & $17.50 \mathrm{~b}$ & $32.00 \mathrm{a}$ & $19.66 \mathrm{a}$ \\
Copaiba & $15.92 \mathrm{~b}$ & $31.50 \mathrm{a}$ & $18.00 \mathrm{a}$
\end{tabular}

${ }^{1}$ Mycoshield $^{\circledR}=$ agricultural antibiotic at a concentration of $3 \mathrm{~g} \mathrm{~L}^{-1}$ and essential oils at $0.5 \%$; Control $1=$ plants treated with water and inoculated with Pectobacterium carotovorum subsp. carotovorum; Control $2=$ plants treated with water only and no pathogen; ${ }^{2} \mathrm{~L}^{*}$ : measures the luminosity, varying from 100 for a perfectly white surface to zero for black; a*: measures the amount of red when positive, gray when zero and green when negative; $b^{*}$ : measures the amount of yellow when positive, gray when zero and blue when negative; ${ }^{3}$ Numbers are the averages of two experiments (ten repetitions). Averages followed by the same letter do not differ significantly by the Kruskal-Wallis test ( $\mathrm{P} \leq 0.05)$ 
Table 4 - Physical and chemical characteristics of Chinese cabbage plants treated with essential oils and the agricultural antibiotic Mycoshield ${ }^{\circledR}$ in the greenhouse

\begin{tabular}{lcclc}
\hline \multicolumn{1}{c}{ Treatment $^{1}$} & ${\text { Ascorbic } \mathrm{acid}^{2}\left(\mathrm{mg}^{5} \mathrm{~g}^{-1}\right)}^{\mathrm{TA}}(\%$ citric acid $)$ & $\mathrm{pH}$ & ${ }^{\circ}$ Brix \\
\hline Mycoshield $^{\circledR}$ & $3.80^{3} \mathrm{a}$ & $0.26 \mathrm{a}$ & $6.33 \mathrm{ab}$ & $0.87 \mathrm{c}$ \\
Control 1 & $3.79 \mathrm{a}$ & $0.25 \mathrm{ab}$ & $6.35 \mathrm{ab}$ & $0.90 \mathrm{c}$ \\
Bergamot & $1.80 \mathrm{~b}$ & $0.15 \mathrm{c}$ & $6.06 \mathrm{~b}$ & $2.16 \mathrm{a}$ \\
Eucalyptus citriodora & $2.06 \mathrm{~b}$ & $0.21 \mathrm{abc}$ & $6.21 \mathrm{ab}$ & $1.90 \mathrm{ab}$ \\
Spearmint & $2.38 \mathrm{~b}$ & $0.23 \mathrm{ab}$ & $6.36 \mathrm{ab}$ & $1.00 \mathrm{c}$ \\
Control 2 & $2.69 \mathrm{~b}$ & $0.15 \mathrm{c}$ & $6.27 \mathrm{ab}$ & $1.00 \mathrm{c}$ \\
Sweet orange & $2.63 \mathrm{~b}$ & $0.15 \mathrm{c}$ & $6.18 \mathrm{ab}$ & $1.73 \mathrm{~b}$ \\
Copaiba & $2.48 \mathrm{~b}$ & $0.20 \mathrm{bc}$ & $6.49 \mathrm{a}$ & $1.00 \mathrm{c}$ \\
CV $(\%)$ & 17.94 & 17.44 & 3.00 & 15.85 \\
\hline
\end{tabular}

${ }^{1}$ Mycoshield ${ }^{\otimes}=$ agricultural antibiotic at a concentration of $3 \mathrm{~g} \mathrm{~L}^{-1}$ and essential oils at $0.5 \%$; Control $1=$ plants treated with water and inoculated with Pectobacterium carotovorum subsp. carotovorum; $\mathrm{Control} 2=$ plants treated with water only and no pathogen $;{ }^{2}$ Ascorbic acid $=$ vitamin C; AT $=$ total titratable acidity; $\mathrm{pH}=$ potential of hydrogen; ${ }^{\circ} \mathrm{Brix}=$ level of total soluble solids; ${ }^{3} \mathrm{Númbers}$ are the averages of two experiments (ten repetitions). Averages followed by the same letter do not differ significantly by Tukey test $(\mathrm{P} \leq 0.05)$

40 days in the greenhouse. The values found for total titratable acidity and $\mathrm{pH}$ however, are close to the 0.13 and 5.95 reported in the literature for minimally processed Chinese cabbage (EVANGELISTA et al., 2009). The increase in ${ }^{\circ}$ Brix was not harmful, since it can vary according to species, cultivar, stage of maturity and climate. For vegetables, the ${ }^{\circ}$ Brix shows an average value of between 2 and 5\% (CHITARRA; CHITARRA, 2005), which was not exceeded when the oils were applied.

\section{CONCLUSION}

The essential oils of copaiba, sweet orange, spearmint, E. citriodora and bergamot, all at $0.5 \%$, were stable in their reduction of the severity of soft rot in Chinese cabbage, and did not alter the colorimetry of the leaves or the physicochemical characteristics of the plants, showing potential for being used as a measure in controlling the disease.

\section{ACKNOWLEDGEMENT}

The authors wish to thank FACEPE for their funding (APQ-0583-5.01/08) and the Master's scholarship granted to the author. The authors also wish to thank $\mathrm{CNPq}$ for the research-productivity grants awarded (Proc. 309697/2011-5 and Proc. 307348/2011-3).

\section{REFERENCES}

ABLE, A. J. et al. The physiology of senescence in detached pak choy leaves (Brassica rapa var. chinensis) during storage at different temperatures. Postharvest Biology and Technology, v. 35, n. 3, p. 271-278, 2005.

ALVARADO, I. C. M. et al. Characterization and variability of soft rot-causing bacteria in Chinese cabbage in North Eastern Brazil. Journal of Plant Pathology, v. 93, n. 1, p. 173-181, 2011.

BURT, S. Essential Oils: their antibacterial properties and potential applications in foods - a review. International Journal of Food Microbiology, v. 94, n. 3, p. 233-253, 2004.

CENTRO DE ABASTECIMENTO E LOGÍSTICA DE PERNAMBUCO. Calendário de comercialização e outras informações de hortigranjeiros. Recife: Secretaria de Agricultura, 2013. 4 p. Disponível em: < http://www.ceasape. org.br/calend.php >. Acesso em: 01 mar. 2014.

CENTRO NACIONAL DE PESQUISA EM HORTALIÇAS (EMBRAPA Hortaliças), 2010. Disponível em: http://www. cnph.embrapa.br/paginas/ serie_documentos/outros/tabela_ nutricional.pdf. Acesso em: 01 mar. 2014.

ChITARra, M. I. F.; ChitarRA, A. B. Pós-colheita de frutas e hortaliças: fisiologia e manuseio. 2. ed. Lavras: UFLA, 2005. $785 \mathrm{p}$

COSTA, A. S. et al. Armazenamento de hastes florais de Heliconia bihai (L.) cv. Lobster Claw em baixa temperatura. Revista Brasileira de Engenharia Agrícola e Ambiental, v. 15, n. 9, p. 966-972, 2011.

COSTA, C. M. G. R. et al. Inibição do crescimento bacteriano in vitro de Erwinia carotovora pelo óleo essencial de alecrim. Tecnologia \& Ciência Agropecuária, v. 2, n. 2, p. 7-10, 2008. 
COSTA, C. M. G. R. et al. Efeito inibitório do óleo essencial de manjericão sobre o crescimento in vitro de Erwinia carotovora. Tecnologia \& Ciência Agropecuária, v. 3, n. 3, p. 35-38, 2009.

EDGINTON, L. V.; KHEW, K. L.; BARRON, G. L. Fungitoxic spectrun of benzimidazole compounds. Phytopathology, v. 61, n. 1, p. $42-44,1971$.

EVANGELISTA, R. M. et al. Qualidade de couve-chinesa minimamente processada e tratada com diferentes produtos. Ciência e Tecnologia de Alimentos, v. 2, n. 29, p. 324-332, 2009.

FREIRE, A. G. et al. Qualidade de cultivares de alface produzida em condições salinas. Caatinga, v. 22, n. 4, p. 8188, 2009.

GUIMARÃES, S. S. et al. Indução de fitoalexinas em cotilédones de soja (Glycine max) em resposta a aplicação de óleos essenciais extraídos de folhas de plantas medicinais. In: SEMINÁRIO SISTEMAS DE PRODUÇÃO AGROPECUÁRIA, 1., 2007, Dois Vizinhos. Anais... Dois Vizinhos: Universidade Tecnológica Federal do Paraná, 2007. 1 CD-ROM.

JEONG, M. R. et al. Essential oil prepared from Cymbopogon citrates exerted an antimicrobial activity against plant pathogenic and medical microorganisms. Mycobiology, v. 37, n. 1, p. $48-52,2009$.

LUCAS, G. C. et al. Indian clove essential oil in the control of tomato bacterial spot. Journal of Plant Pathology, v. 94, n. 1, p. 45-51, 2012.
MARIANO, R. L. R.; SILVEIRA, E. B. Manual de Práticas em Fitobacteriologia. 2. ed. Recife: UFRPE, 2005. 184 p.

MELLO, M. R. F. et al. Uso de antibióticos e leveduras para controle da podridão mole em couve-chinesa. Horticultura Brasileira, v. 29, n. 1, p. 78-83, 2011.

MORAIS, L. A. S. Óleos essenciais no controle fitossanitário. In: BETTIOL,W.; MORANDI, M. A. B. Biocontrole de doenças de plantas: uso e perspectivas. Jaguariúna: Embrapa Meio Ambiente, 2009. p. 139-152.

REN, J.; PETZOLDT, R.; DICKSON, M. H. Genetics and population improvement resistance to bacterial soft in Chinese cabbage. Euphytica, v. 117, n. 3, p. 197-207, 2001.

SHANER, G.; FINNEY, R. E. The effect of nitrogen fertilization 433 on the expression of slow-mildewing resistance in knox wheat. Phytopathology, v. 67, n. 8, p. 1051-1056, 1977.

SILVA, A. M. F. et al. Levantamento da intensidade da podridão mole em alface e couve- chinesa em Pernambuco. Caatinga, v. 20, n. 2, p. 84-93, 2007.

SILVA, C. L. et al. Óleos essenciais e extratos vegetais no controle da podridão mole em alface crespa. Horticultura Brasileira, v. 30, n. 4, p. 632-638, 2012.

ZENEBON, O.; SADOCCO, N.; TIGLEA, P. Métodos físico-químicos para análises de alimentos. 4. ed. São Paulo: Instituto Adolfo Lutz, 2008. 1020 p. 